logous Rhizcbium species use the apparatus induced by $R$. leguminosarum so that there is a partial breakdown in specificity. The strains of $R$. trifolii and $R$. phaseoli used do not ordinarily induce nodules on peas but we do not know if they form infections which abort before nodule formation. $R$. trifolii was unable to fix nitrogen in pea nodules. This suggests that more than one barrier prevents Rhizobium of one cross-inoculation group forming an cffective symbiosis with a legume of a different group. This is in accord with the findings that mutants of $R$. trifolii able to nodulate peas did not fix nitrogen in this host ${ }^{1}$ and that some strains of Rhizobium isolated from clover formed ineffective nodules on peas ${ }^{2}$.

ANDREW W. B. JOHNSTON

JOHN E. BERINGER

Department of Genetics,

John Innes Institute,

Colney Lane, Norwich NR4 7UH, UK

Received July 21; accepted August 27, 1976.

1 Schwinghamer, E. A., Am. J. Bot., 49, 269-277 (1962).

Kleczkowska, J., Nutman, B. P. S.; and Bond, G., J. Bact., 48, 673-675 (1944).

Hepper, C. M., Rothamsted Experimental Station Report, 282 (1975).

W. Phytophylactica, 3, 125-130

Johnston, A. W. B., and Beringer, J. E., J. appl. Bact., 40, 375-380, (1976).

Johnston, A. W. B., and Beringer, J. E., J. gen. Microbiol., 87, 343-350 (1975).

Higashi, S., J. gen. appl. Microbiol., 13, $391-403$ (1967).

Laine, R. T., and Alexander, M., Can. J. Microbiol., 7, 959961 (1961).

Beringer, J. E., J. gen. Microbiol., 84, 188-198 (1974).

\section{Erucic acid, an accidental additive in bread}

RAPESEED oil is a stable, viscous oil utilised extensively by the baking industry in several countries as a lubricant to prevent the dough piecc sticking to the container during baking. The oil is applied either to the container or directly on to the dough surface and allows the easy removal of the bread after baking. There are, however, few data available to indicate the extent to which any rapeseed oil is absorbed into the bread during processing. The question has assumed considerable importance since Roine ${ }^{l}$ and many subsequent workers $^{2}{ }^{4}$ showed that a range of laboratory animals developed heart lesions and other biochemical abnormalitics when fed diets with a substantial content of rapeseed oil. These effects have generally been attributed to erucic acid" (13-docosenoic acid) which is the major fatty acid constituent in normal rapeseed oils $(30-50 \%$ of total fatty

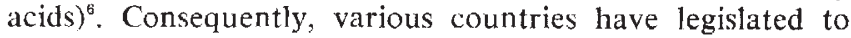
restrict the amount of erucic acid permitted in certain foods, although no tolerances have been set specifically for baked products. This is mainly due to the assumption that erucic acid is not a natural component of the ingredients used in bread.

We have examined 20 different types of bread obtained from retail outlets in Sydney, Australia and found that all loaves contained erucic acid in concentration which ranged from 170 to $1,070 \mathrm{mg}$ of erucic acid per $\mathrm{kg}$ of fresh loaf, with an average concentration of $405 \mathrm{mg} \mathrm{kg}^{-1}$. A sample of wheat flour was also analysed but no erucic acid was detected $\left(<0.2 \mathrm{mg} \mathrm{kg}^{-1}\right)$, and so the erucic acid in the breads can be assumed to be derived from the rapeseed oil applied just before baking. The breads analysed included plain and fancy rolls, and standard loaves of white, brown, wholemeal, rye, kibble wheat, soy flour-wheat and starch-reduced breads. The breads were dried and ground, and a sample $(20 \mathrm{~g})$ was extracted with solvent to remove the lipids which were saponified and methylated ${ }^{7}$, and analysed by flame ionisation gas chromatography using a 10\% DEGS-PS on Supelcoport $(80 / 100)$ glass column at $190^{\circ} \mathrm{C}$ with a carrier gas flow rate of $20 \mathrm{ml}$ per min of nitrogen.

Measurements were also made of the distribution of erucic acid throughout a single loaf. Table 1 shows that most of the erucic acid was present in the outer layer
Table 1 Distribution of erucic acid in a bread loaf $(15 \mathrm{~cm}$ high)

\begin{tabular}{lc} 
Position in loaf & mg erucic acid per $\mathrm{kg}$ \\
Base $-0.2 \mathrm{~cm}$ into loaf & 9,550 \\
$\left.\begin{array}{lc}0-1.0 \mathrm{~cm} & 1,760\end{array}\right\} 3,320^{*}$ \\
$1.0-3.0 \mathrm{~cm}$ & 50 \\
$3.0-7.5 \mathrm{~cm}$ (centre of loaf) & 40 \\
\hline
\end{tabular}

*Overall value for bread from base to $1.0 \mathrm{~cm}$.

although some was found in the centre of the loaf. If these gradients can be applied to all loaves, then the crust slice ( $1 \mathrm{~cm}$ thick) would contain appreciable amounts of erucic acid and range from about 0.15 to $1.0 \%(\mathrm{w} / \mathrm{w})$ of the crust.

Although much information has been obtained during the past $5 \mathrm{yr}$ on the effects of erucic acid on animals, negligible data are available on its toxicological effects on man, and so it has been difficult to set meaningful levels of erucic acid permissible in human diets. An acceptable daily intake of rapeseed oil has been estimated to be $30 \mathrm{mg}$ per $\mathrm{kg}$ of body weight ${ }^{8}$, which is equivalent to about $12 \mathrm{mg}$ of erucic acid per $\mathrm{kg}$. Our data show that an adult would achieve this intake if of the order of $1 \mathrm{~kg}$ of bread was eaten per day, although more than half the daily allowance would be supplied by two crust slices. Children, however, could receive more than their total allowable intake with only two crust slices. Thus, the use of rapeseed oil as a release agent in the baking industry leads to contamination of the product with erucic acid of a magnitude sufficient to cause concern for public health. The continued use of this substance on bread should therefore be reviewed. There are rapeseed oils readily available on the international market with low erucic acid contents $(<1 \%)^{9}$ and these could be investigated for use in the baking industry. It is probable, however, that the viscosity of these oils would not be as desirable as that of high-erucic rapeseed oils, in which case, blending with other components would be necessary.

\section{R. B. H. WILLS \\ M. WOOTTON \\ G. HOPKIRK}

School of Food Technology,

University of New South Wales,

Kensington, Australia 2033

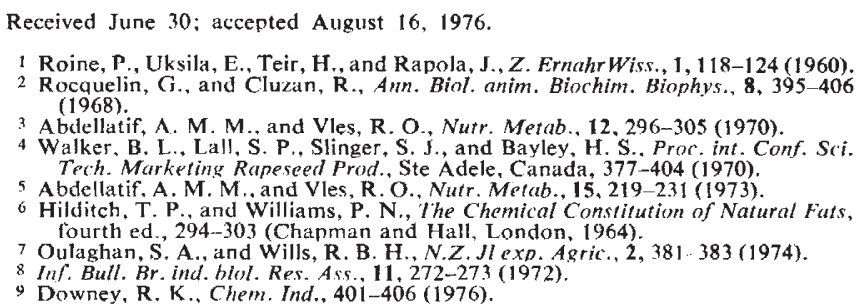

Received June 30; accepted August 16, 1976.

1 Roine, P., Uksila, E., Teir, H., and Rapola, J., Z. ErnahrWiss., 1, 118-124 (1960). Rocquelin, G., and Cluzan, R., Ann. Biol. anim. Biochim. Biophys., 8, 395-406 (1968).

3 Abdellatif, A. M. M., and Vles, R. O., Nutr. Metab., 12, 296-305 (1970).

Walker, B. L., Lall, S. P., Slinger, S. J., and Bayley, H. S., Pror int. Conf. Sci. Tech. Marketing Rapeseed Prod., Ste Adele, Canada, 377-404 (1970).

5 Abdellatif, A. M. M., and Vles, R. O., Nutr. Metab., 15, 219-231 (1973).

Hilditch, T. P., and Williams, P. N., The Chemical Constitution of Natural Fats, fourth ed., 294-303 (Chapman and Hall, London, 1964)

Oulaghan, S. A., and Wills, R. B. H., N.Z. Jl exp. Agric., 2, 381 383 (1974).

Inf. Bull. Br. ind biol. Res. Ass., 11, 272-27,3 (1972)

Downey, R. K. Chem. Ind 401-406 (1976).

\section{Suppression of adenocarcinoma by the immunological consequences of calorie restriction}

EARLIER extensive studies have indicated that calorie restriction as well as protein and amino acid restriction inhibit the spontaneous development of mammary or lung adenocarcinomas, hepatomas and certain chemical carcinogen-induced tumours in rodents ${ }^{1-4}$. Jose and Good $^{5-7}$ and Cooper et al. ${ }^{8}$ have shown that chronic moderate protein deprivation in mice and rats dramatically depresses antibody production while increasing, or permitting maintenance of, vigorous cell-mediated immune responses. The latter include abilities to resist virus infection, reject skin allografts and develop killer-cell activity 